\title{
Submucosal 2 Invasion
}

National Cancer Institute

\section{Source}

National Cancer Institute. Submucosal 2 Invasion. NCI Thesaurus. Code C155964.

Submucosal tumor invasion into the middle third of the submucosal tissue. 